\title{
Jewish lobby as an overlooked power which leads to political transformations in US foreign policy
}

УдК 328.1

DOI https://doi.org/10.24195/2414-

9616.2021-4.18

Aleskerova Sara Tahir

Doctoral Student

Baku State University

Academician Zakhid Khalilov str., 23, Baku, Azerbaijan

\begin{abstract}
Purpose of the article. This research containes discussion of the role of Jewish lobby in US foreign policy. The lobby is a loose coalition of individuals and organizations that actively works to move U.S. foreign policy. In short, lobbying is the overlooked power which is able to make considerable political transformations in foreign policy. Furthermore, a more detailed account about the power of Israel's lobby especially toward the arab lobby's interests in the US congress were investigated. This article is a broader research on identifying the real reasons of America's support of Israel lobby and why yet it is clearly more difficult for Americans to talk openly about the Israel lobby.

Methods. The methodology of the research involves using the qualitative methods including content analysis, discourse anylysis. Moreover, the study is based on systematic and comporative approaches to the analysis of the "overlooked influence of jewish lobby" in decion making process in the US congress. The main sources for the analysis are reports of researchers John Mearsheimer and Stephen Walt about The Israel Lobby and U.S. Foreign Policy. These reports pay a great attention to impact of israel lobby on USA foreign policy especially towards arab lobby in the Middle East.

Novelty. For the first time in the domestic scientific literature will use the analysis of existing rules, documents, recommendations, research, experience, as well as expert criticism on lobbying European communities in the world's superpowers.

Results. All in all if Israel's interests did not match american own political interests the government would not open the door for Jews' lobby. Addionally, I do not agree with the suggestion that US Congress was based on the "Money Talks" system, in other words, "the American Congress was run by money". If that were the case, then rich Arab companies which are considered to be lucrative oil lobbies would play a significant role in the US Congress. The United States does not blindly open its doors for all lobbying activities just for the sake of money. The opening of the door in the system depended on who knocked on it. It's hard to know where one driver of America's Israel policy ends and another begins. Key words: US congress, Jewish lobby, lobbying, US support, political transformations.
\end{abstract}

Introduction. Today lobbying success is qualitatively measured by change in policy outcome by comparing stated goals of selected interest groups to political outputs. But at the same time, we need to be able to talk openly and calmly about all the forces that shape U.S. politics today, including groups like AIPAC (American İsrael Public Affairs Committee) and related organizations that seek to influence U.S. foreign policy. Unlike the business or enviromental interest groups which concerned with profits and social values, respectively, ethnich interest groups are concerned with the well-being of members of the self-defined ethnich group, wherever they reside. Consequently, one can define ethnic lobbies as a political organizations established along cultural, ethnic, religious or racial lines that seek to directly and undirectly influence US foreign policy in support of their homeland and ethnic kin in abroad [3, p. 2].

Methods and materials. The methodological basis of the research is approach of George Mearsheimer and Stewen Watson about the influence of jewish lobby on American Congress. This research describes the remarkable level of material and diplomatic support that the United States provides to Israel and argues that this support cannot be fully explained on either strategic or moral grounds. This exceptional relationship is due largely to the political influence of a loose coalition of individuals and organizations that actively work to shape U.S. foreign policy in a proIsrael direction [6]. Furthermore, Lester W. Milbrath's book called "Washington Lobbysits" is used in this research as the best explainer of how work a decision making proses in American Congress [7]. This study is based on systematic and comporative approaches to the analysis of the decision making process in the US congress and real reasons of American support to Israel. Approaches of critics of Jewish lobbies' activities also icluded to this research [1, p. 8]. Given the size and status of the American Jewish community in international Jewry it is not surprising that a great many analysts have focused critical attention on this community and its Israel-related political agencies and activities. Yet despite the lobby's efforts a considerable number of Americans-almost 40 percent-recognize that US support for Israel is one of the main causes 
of anti-Americanism around the world. Among elites, the number is substantially higher [5, p.4]. Furthermore, a surprising number of Americans understand that the lobby has a significant, not always positive influence on the US foreign policy. In a 2006 survey of international relations scholars in the United States, 66 percent of the respondents said that they agreed with the statement "the Israel lobby has too much influence over U.S. foreign policy. While the American people are generally sympathetic to Israel, many of them are critical of particular Israeli policies and would be willing to with hold American aid if Israel's actions are seen to be contrary to U.S. interests [5, p. 11-13].

Analysis. It is well- known fact that from the perspective of ethnic politics in America the proIsrael and pro-Arab groups lie at the two extremes of a continuum of power and impact. Jewish lobby is known as the most cohesive, articulate, influential and powerfull groups in America. Their influence and aggregate term that refers to the preceding characteristics is measured by their ability to sustain in America a posture of strong support for Israel. However, the arab lobby which is in stark contrast to their counterparts are considered some of the least cohesive, least articulate and weakest lobby groups in America. And of course, with a low power and low influence quotient [1, p.1]. However, some researchers believe that there was no pro-Jewish president in the United States before Clinton. Clinton was the president who often organize meetings with Israeli prime ministers and diplomats in American history [9, p. 9-11].

There are a number of Jewish officials in the current US President Donald Trump's team. Trump, like all previous presidents in American history, pays special attention to his relations with Israel. As a result, Trump held his first official telephone conversation with foreign leaders with Israeli Prime Minister Benjamin Netanyahu after the presidential election. As for the Arab-Israeli conflict, I think Trump is no exception among US politicians. So it is no coincidence that Israel was once called the "51st state" of the United States. History has shown that the United States has always supported Israel since its inception [11, p. 239-242].

What's the thinking behind America going above-and-beyond for Israel? The short version: it's complicated. The long version is that It's a tight interplay of America's long-running Middle East strategy, US public opinion/electoral politics, and a pro-Israel lobbying campaign that is effective, but maybe not as effective as you've heard. Here's a guide to the different factors shaping America's Israel policy - and how they relate to each other. The jewish lobby is a loose coalition of individuals and organizations that actively works to move U.S. foreign policy in a pro-Israel direction. Like the efforts of other ethnic lobbies and interest groups, the activities of the Israel lobby's various elements are legitimate forms of democratic political participation and they are for the most part consistent with America's long tradition of interest group activity The United States has played an important and steadily increasing role in Middle East security issues since World War II, driven initially by oil, then by anticommunism and, over time, by its growing relationship with Israel [6, p. 5-7]. The United States is Israel's largest single trading partner. The top five U.S. exports to Israel are: diamonds, semiconductors, civilian aircraft, telecommunications equipment, and agricultural products. The top five U.S. imports from Israel are: diamonds, pharmaceutical products, semiconductors, medicinal equipment, and telecommunications equipment. U.S. direct investment in Israel is primarily in the manufacturing sector, as is Israeli investment in the United States. Another reason for the strength of the Jewish lobby in the United States was its wide representation in government. In the 19th century, jewish Zeligman was a financial adviser to the US government. In modern times Kissinger, S. Vance, Z. Brzezinski, R. Lipschich, P. Zuckerman, S. Eisenstat, M. Albright were 10\% Jewish congressmen in the US Senate and $15 \%$ in the House of Representatives [7, p. 12-14].

The answer to question of "why America always support Israel" in fact is very simple for me: "Because the American people love Israel, they want to assimilate and protect it." Additionally, there are several main reasons for this: The Jewish genocide which called "Holocaust" The American people still do not forget the destruction of half of the world's Jewish population. Another reason is religion. More than 40 million evangelicals in the United States are the biggest supporters of the US-Israeli alliance. Americans see the founding of Greater Israel as a harbinger of Jesus' s return. Israel's strategic importance to the United States is also a very important factor. Oil pipelines from Iraq to the Mediterranean, as well as roads to Egypt and Lebanon, Syria and Jordan, pass through Israel. Israel's airspace allows it to take full control during wars. The last and biggest reason is that the American people have a different point of view on the Israeli-Palestinian issue than the rest of the world. America sees this issue not as the oppression of the Palestinian people, but as a struggle of small 5 million's Israel for survival against the $\mathbf{3 5 0}$ million's Arab world.

Today the goal of the Jewish lobby is to continue the US policy of protecting its independence and integrity and to continue to provide material and financial assistance to Israel in this area. We can say that it has been quite successful in this direction. Statistics show that Israel has long been the largest recipient of $\$ 3$ billion a year in aid from the United States. It should be noted that Egypt is in the second place in this list with 2.4 billion aid per year [11, 
s. 243]. Apparently, the United States is rewarding Egypt in this way because it is the only Arab country that has made peace with Israel. In addition, taking into an account Egypt's military and political power in terms of population, it is impossible for Arab countries to win the war against Israel unless Egypt enters the war. All these factors make Egypt important for Israel's security.

The United States has also undertaken policies in the broader Middle East that reflected Israel's preferences. Since the early 1990 for example, American policy toward Iran has been heavily influenced by the wishes of successive Israeli governments. Tehran has made several attempts in recent years to improve relations with Washington and settle outstanding differences, but Israel and its American supporters have been able to stymie any détente between Iran and the United States, and to keep the two countries far apart. Another example is the Bush administration's behavior during Israel's war against Lebanon in the summer of 2006 [14]. Almost every country in the world harshly criticized Israel's bombing campaign-a campaign that killed more than one thousand Lebanese, most of them civiliansbut the United States did not. Instead, it helped Israel prosecute the war, with prominent members of both political parties openly defending Israel's behavior [6, p. 8]. The Israel lobby has successfully convinced many Americans that American and Israeli interests are essentially identical. In fact, they are not. It is difficult to talk about the lobby's influence on American foreign policy, at least in the mainstream media in the United States, without being accused of anti-Semitism or labeled a self-hating Jew. It is just as difficult to criticize Israeli policies or question U.S. Support for Israel in polite company. America's generous and unconditional support for Israel is rarely questioned, because groups in the lobby use their power to make sure that public discourse echoes its strategic and moral arguments for the special relationship [6, p. 9].

Like other interest groups, the Israel lobby uses a variety of strategies to accomplish its goals. Some of its influence comes from campaign contributions to political parties or politicians (although AIPAC does not do this), some from direct lobbying on Capitol Hill, some from public outreach (op-eds, books, position papers, media appearances, etc.), and some from the role that pro-Israel individuals may play in the U.S. government itself. The main difference between the Jewish lobby and other foreign lobbies in the United States is that while other foreign lobbies spend millions on lobbying activities in the United States through contacts with American lobbying companies, the Israeli lobby does not need to spend large sums. Unlike other countries İsrael does not need lobbying companies. Because 6 million wellorganized Jews scattered in all American states and cities, connected by strong bonds, and apart from this there are a number of supporters in the US Congress [1, p. 12]. American strategic interest on supporting Israel lobby is clear. To guarentee the survival of Israel, all American presidents since Lyndon Johnson have made sure that the balance of military power in the Middle East continues to swing decisively in favor of Israel [8, p.7-9].

But AIPAC doesn't always win. The US wasn't always so close with Israel. For instance, when Israel (along with France and Britain) invaded Egypt in 1956, the United States sided against Israel, pushing the invaders to leave. And the US for years opposed and worked actively against Israel's clandestine nuclear program. "Stated commitments to Israel from American policymakers cannot erase a legacy of US policies that often represented more of a threat than a support to Israeli security," Michael Barnett, George Washington University political scientist says. The US leadership did not help Israel in 1948, when the state of Israel fought for its independence and five Arab states united against this new state. Apart from this the US embargo on arms shipments to Israel [4, p. 277].The US-Israel relationship grew "by leaps and bounds" after 1967, according to Barnett, owing largely to "a changing US containment and strategic posture." American presidents and strategists came to see Israel as a useful tool for containing Soviet influence in the Middle East, which was significant among Arab states, and used diplomatic and military support to weave Israel firmly into the anti-Soviet bloc [13, p. 27-31].

Why it is so hard to talk about the Israel lobby? Because the United States is a pluralist democracy where freedom of speech and association are guaranteed, it was inevitable that interest groups would come to dominate the political process. For a nation of immigrants, it was equally inevitable that some of these interest groups would form along ethnic lines and that they would try to influence U.S. foreign policy in various ways Cuban Americans have lobbied to maintain the embargo on Castro's regime, Armenian Americans have pushed Washington to acknowledge the 1915 genocide and, more recently, to limit U.S. relations with Azerbaijan and Indian Americans have rallied to support the recent security treaty and nuclear cooperation agreements. Such activities have been a central feature of American political life since the founding of the country, and pointing them out is rarely controversial. Yet it is clearly more difficult for Americans to talk openly about the Israel lobby. Part of the reason is the lobby itself, which is both eager to advertise its clout and quick to challenge anyone who suggests that its influence is too great or might be detrimental to U.S. interests.

Any discussion of Jewish political power takes place in the shadow of two thousand years of history, especially the centuries of very real anti-Semitism in 
Europe "Jews control the media." Similarly, if someone points out that American Jews have a rich tradition of giving money to both philanthropic and political causes, it sounds like they are suggesting that "Jewish money" is buying political influence in an underhanded or conspiratorial way. Of course, anyone who gives money to a political campaign does so in order to advances political cause, and virtually all interest groups hope to mold public opinion and are interested in getting favorable media coverage [10, p.13].

Conlusion. The strength of the Jewish lobby in the United States is related to the sympathy and closeness of the American community to Israel. That is why the idea that the US Congress is run by Jews is widespread in the international arena. However, in my opinion, those who have a deep understanding of how the lobby system works in America do not believe in such a theory. It is true that the influence of the Israeli lobby in America is undeniable. However, there are other foreign lobbies that are at least as influential as the Jewish lobby. If the United States was ruled by the Israeli lobby, Egypt would not be able to receive about $\$ 2$ billion in aid from Washington each year. In my opinion, if Israel's interests did not match american own political interests the government would not open the door for Jews' lobby. Addionally, I do not agree with the thought that US Congress was based on the "Money Talks" system, in other words, "the American Congress was run by money". If it were so rich Arab companies which are considered to be lucrative oil lobbies would play a considerable role in the US Congress. The United States does not blindly open its doors for all lobbying activities just for the sake of money. The opening of the door in the system depended on who knocked on it. It's hard to know where one driver of America's Israel policy ends and another begins. American policymakers have seen US support for Israel as a way of showing Israel that the US is still taking its interests into account during negotiations, and thus convincing Israel that they can safely engage in peace talks. It's meant to draw the Israelis to the negotiating table, and keep them there.

\section{REFERENCES:}

1. Ahrari Mohammed E. (1987), Ethnic Groups and U.S. Foreign Policy. New York, Greenwood Press, 178 p.

2. Ambrosio Thomas (2002). Ethnic identity groups and U.S. foreign policy. Westport, Praeger Publishers Inc, $240 \mathrm{p}$.

3. Beck Robert J. and Thomas Ambrosio (2002). International Law and the Rise of Nations: The State System and the Challenge of Ethnic Groups. University of Wisconsin-Milwaukee, Sage Publications, 364 p.

4. Flapan Simha (1987). The Birth of Israel: Myths and Realities. New-York, Pantheon Books, 277 p.

5. Goldberg, David Howard (1990). Foreign Policy and Ethnic Interest Groups: American and Canadian Jews Lobby for Israel. New York, Greenwood Press, 197 p.
6. John Mearsheimer, Stephen Walt (2006). The Israel Lobby and U.S. Foreign Policy. London, March. $467 \mathrm{p}$.

7. Lester W. Milbrath (1963). Washington Lobbysits. Chicago, Rand McNally, $452 \mathrm{p}$.

8. Paul David M. and Rachel Anderso (2009). Ethnic Lobbies and US Foreign Policy. Western Washington Univeresity, Lynne Rienner Publishers, 261 p.

9. Prudnik I.V. (1984) Sionistskoye lobbi v SSHA. Minsk: "Belarus", Zionist lobby in the USA. Belarus, Minsk, $64 \mathrm{p}$.

10. Samuel Goldman (2019). The Real Reason Americans Support Israel (Hint: It's Not AIPAC). 14 february. URL: https://www.tabletmag.com/sections/ news/articles/the-real-reason-americans-support-israel (accessed 2 august 2020).

11. Tayyar Arı (2000). Political Structure, Lobbies and Foreign Policy in America Turkey, Istanbul, Alfa Press, 3th edition, Ocak. 310 p.

12. Ties Between Israel and US "Worst in 35 Years" (2010), BBC News, 15 March, URL: http://news.bbc. co.uk/2/hi/middle_east/8567706.stm (accessed 2 august 2020).

13. Xhalil Marrar (2020). Arab lobby and US foreign policy. URL: http://www.ozetkitap.com/kitaplar/arap_ lobisi.pdf (accessed 2 august).

14. Zack Beauchamp (2014). Why the US has the most pro-Israel foreign policy in the world. July 24 , 2014. URL: https://www.vox.com/2014/7/24/5929705/ us-israel-friends (accessed 2 august 2020).

\section{ЛITEPATУPA:}

1. Ahrari Mohammed E. Ethnic Groups and U.S. Foreign Policy. New York, Greenwood Press, 1987. $178 \mathrm{p}$.

2. Ambrosio Thomas. Ethnic identity groups and U.S. foreign policy. Westport, Praeger Publishers Inc, 2002. 240 p.

3. Beck Robert J. and Thomas Ambrosio. International Law and the Rise of Nations: The State System and the Challenge of Ethnic Groups. University of Wisconsin-Milwaukee, Sage Publications, 2002. $364 \mathrm{p}$.

4. Flapan Simha. The Birth of Israel: Myths and Realities. New-York, Pantheon Books, 1987. 277 p.

5. Goldberg, David Howard. Foreign Policy and Ethnic Interest Groups: American and Canadian Jews Lobby for Israel. New York, Greenwood Press, 1990. $197 \mathrm{p}$.

6. John Mearsheimer, Stephen Walt. The Israel Lobby and U.S. Foreign Policy. London, 2006 march. $467 \mathrm{p}$.

7. Lester W. Milbrath. Washington Lobbysits . Chicago, Rand McNally, 1963. 452 p.

8. Paul David M. and Rachel Anderso. Ethnic Lobbies and US Foreign Policy. Western Washington Univeresity, Lynne Rienner Publishers, 2009. 261 p.

9. Прудник И.В. Сионистское лобби в США. Минск: "Беларусь", 1984. 64 с.

10. Samuel Goldman. The Real Reason Americans Support Israel (Hint: It's Not AIPAC). 14 february. 2019 URL: https://www.tabletmag.com/sections/news/ articles/the-real-reason-americans-support-israel (accessed 2 august 2020). 
11. Tayyar Arı. Political Structure, Lobbies and Foreign Policy in America Turkey, Istanbul, Alfa Press, 3th edition, Ocak 2000. 310 p.

12. Ties Between Israel and US "Worst in 35 Years", BBC News, 15 March 2010, URL: http://news.bbc. co.uk/2/hi/middle_east/8567706.stm (accessed 2 august 2020).
13. Xhalil Marrar. Arab lobby and US foreign policy. URL: http://www.ozetkitap.com/kitaplar/arap_lobisi.pdf (accessed 2 august 2020).

14. Zack Beauchamp. Why the US has the most proIsrael foreign policy in the world. July 24, 2014. URL: https://www.vox.com/2014/7/24/5929705/us-israelfriends (accessed 2 august 2020).

\title{
Єврейське лобі як недооцінена сила, що призводить до політичних трансорормацій у зовнішній політиці США
}

Алєскєрова Сара Тахір

докторант

Бакинського державного університету вул. Академіка Західа Халілова, 23,

Баку, Азербайджан

\begin{abstract}
Це дослідження містить обговорення ролі єврейського лобі у зовнішній політиці США. Лобі-це вільна коаліція окремих осіб іорганізацій, яка активно працює над просуванням зовнішньої політики США. Іншими словами, лобіювання - це та недооцінена влада, яка здатна призвести до значних політичних перетворень у зовнішній політиці. Окрім того, проведено більш докладне дослідження про силу ізраїльського лобі, особливо проти інтересів арабського лобі в Конгресі США. Ця стаття являє собою більш широкий аналіз з виявлення реальних причин, за якими Америка підтримує ізраїльське лобіювання і чому американцям складно відкрито говорити про ізраїльське лобі.

Методологія дослідження включає у себе використання якісних методів, таких як контент і дискурс-аналіз. Більше того, дослідження засноване на систематичному і компілюючому підходах до аналізу поняття «недооцінений вплив єврейського лобі» на процес прийняття рішень у Конгресі США. Основними джерелами аналізу є звіти дослідників Джона Міршеймера і Стівена Уолта про ізраїльське лобі у зовнішній політиці США. У цих звітах велика увага приділяється впливу ізраїльського лобі на зовнішню політику США, особливо проти арабського лобі на Близькому Сході.

Уперше у вітчизняній науковій літературі проведено аналіз існуючих правил, документів, рекомендацій, дослідницьких робіт, досвіду, а також експертної критики з питань лобіювання єврейських громад у супердержавах світу.

Якби інтереси Ізраїлю не збігалися з американськими політичними інтересами, уряд США не відкрив би двері для єврейського лобі. Окрім того, авторка не згодна 3 думкою, що Конгрес США був заснований на системі «грошових переговорів», іншими словами, що «американський Конгрес управляється грошима». Якби це було так, тоді багаті арабські компанії, які вважаються прибутковими нафтовими лобі, грали б значну роль у Конгресі США. Сполучені Штати Америки не відкривають сліпо свої двері для будь-якої лобістської діяльності лише заради грошей. Відкриття дверей у системі залежить від того, хто в неї постукав. Важко зрозуміти, де закінчується одна рушійна сила політики Америки щодо Ізраїлю і де починається інша. Ключові слова: Конгрес США, єврейське лобі, лобіювання, підтримка США, політичні трансорормації.
\end{abstract}

